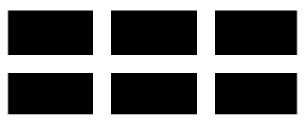

The WiLliam DAVIDSON Institute AT THE UNIVERSITY OF MICHIGAN BUSINESS SCHOOL

Enterprise Restructuring and Firm Performance: A Comparison of Rural and Urban Enterprises in Jiangsu Province

By: Xiao-yuan Dong, Louis Putterman and Bulent Unel

William Davidson Institute Working Paper Number 668 March 2004 


\title{
Enterprise Restructuring and Firm Performance: A Comparison of Rural and Urban Enterprises in Jiangsu Province
}

\author{
Xiao-yuan Dong \\ Department of Economics \\ University of Winnipeg \\ Louis Putterman \\ Department of Economics \\ Brown University \\ Bulent Unel \\ Department of Economics \\ Brown University
}

February, 2004

\begin{abstract}
:
We examine the contrast in the experience of ownership reforms between urban SOEs and rural TVEs using a panel of industrial enterprises in Nanjing municipality for the period from 1994 to 2001. Our objectives are twofold. First, we study how the reform program of "grasp the large and let go of the small" has been carried out in practice by comparing the patterns of enterprise restructuring in the SOEs and the TVEs. Second, we investigate how the alternative reform strategy has affected firm performance in terms of the growth of labor productivity, total factor productivity (TFP), profitability, and worker earnings. We find a sharp contrast in the reform strategies of the SOEs and TVEs in two respects. First, the changes in the SOE sector were more gradual and involved more limited transfer of property rights than did the reform of the TVEs. Secondly, the reforms in both sectors exhibited selection bias but in opposite directions, with worse performing ones being the principal targets of reforms, among SOEs, and better performing enterprises being more likely to be picked for privatization, among TVEs. Our analysis discerns strikingly strong, robust positive effects of ownership restructuring on the growth of labor productivity, TFP and profitability in the reformed SOEs, indicating that the evolutionary reform policy for the SOEs has successfully reversed the trends of declining productivity and profits in these enterprises in Nanjing. We also find that among reformed urban enterprises, those in which private ownership accounts for less than $50 \%$ of shares performed better than those in which the majority of shares are owned privately. We find mixed evidence for the TVEs: privatization had no effect on firm performance in a group fixed-effects model but significant, positive effects in a firm fixed-effects model.
\end{abstract}

Keywords: China, ownership reform, privatization, SOE, TVE

JEL codes: P31, P26, P23 


\section{Enterprise Restructuring and Firm Performance: A Comparison of Rural and Urban Enterprises in Jiangsu Province}

\section{Introduction*}

Since the early 1980s, privatization has been a widely adopted strategy for addressing governance problems in publicly owned enterprises throughout the world. However, privatizing large enterprises is a formidable task for transition economies where market institutions are weak and private capital is largely unavailable. Despite the obstacles, most transition countries in Central and Eastern Europe have carried out privatization at high speed. The rapid mass privatization was achieved primarily through subsidized management-employee buyouts and equal-access voucher schemes (Gray, 1996).

The privatization experience of Central and Eastern Europe suggests that the "big bang" approach to privatization in the absence of well-functioning market institutions has several undesirable economic and social consequences (Svejnar, 2002). The process did not raise much new capital for privatized enterprises nor did it bring large revenues to the governments concerned. Moreover, without competitive capital markets, the ownership structure created by the privatization process was often either too dispersed for effective governance or else it concentrated too much power in the hands of people who lacked adequate incentives to restructure the enterprises. The resultant inefficient governance structure was difficult to correct because of institutional inertia. Furthermore, in those countries where social networks independent of the ruling Communist party were weak prior to privatization, the non-market approach to privatization led to a high concentration of wealth in the hands of more powerful stakeholders, such as the managers in Russia (Alexeev, 1999; Black, Kraakman and Tarassova, 2000; Roland, 2002).

Unlike the Eastern European countries, China has taken an evolutionary approach to reforming the ownership structure of public enterprises. For the first 15 years of the transition to the market, the reforms of state and collectively owned enterprises focused on the increase of managerial autonomy and the improvement of work incentives, along with the development of non-state sectors and market institutions. In the late 1980s, with rural industries growing more slowly and the financial performance of the urban collective and state sectors deteriorating, some local governments began to privatize locally owned enterprises, known as township and village enterprises (TVEs). In late 1992, China's leaders formally endorsed private property rights and initiated ownership reforms in public enterprises at the $14^{\text {th }}$ Congress of the Chinese Communist Party. While the government decided to withdraw state ownership

\footnotetext{
* This research was carried out with aid of grants from the William Davidson Institute at the University of Michigan Business School, University of Winnipeg, and Brown University.
} 
radically from small- and medium-size enterprises in competitive sectors, the approach to reforming large state-owned enterprises (SOEs), described by the so called "modern enterprises system" program, remained cautious and gradual. Under this program, the government maintains its control over large SOEs in key strategic sectors and reforms these enterprises by converting them into corporations with more clearly defined property rights and transferable ownership. These reform policies, described as "grasp the large and let go of the small" (zhudafangxiao), were reaffirmed during the $15^{\text {th }}$ Congress of the Chinese Communist Party in September 1997. With the spontaneous movement from below and the encouragement from above, China's industry has seen an enormous wave of ownership restructuring since the late $1990 \mathrm{~s}$.

Because ownership restructuring in China's industry is a relatively recent event, empirical studies of the reform process and its impacts have just begun to emerge. Jefferson et al. (2003) provided a statistical description of the ownership reform with the data on the full population of 22,000 large- and medium-size enterprises for the period from 1994 to 1999. They found that during the period of investigation the state's share of both enterprises and assets had fallen to one half and that the declining share of state ownership was correlated with rising rates of growth in labor productivity and total factor productivity in SOEs. Using a survey of 683 SOEs in 11 cities for the years of 1995 to 2001, Garnaut, et. al. (2003) documented the process of ownership restructuring in the state sector. The authors reported that while more than 80 percent of SOEs claimed to have completed property rights reforms, the transformation of ownership from the state to private investors had been rather slow. Yao and Song (2003) examined the impacts of ownership changes on enterprise performance using the same data set. They found that the shift of ownership rights from the state to private investors improved the profitability of firms but had no effect on unit cost and labor productivity. Sun, Tong and Tong (2002) estimated the effects of privatization on SOEs listed on the Shanghai Stock Exchange and the Shenzhen Stock Exchange. An inverted U-shape relationship between firm performance and degree of privatization was found.

A number of empirical studies examined the changes in China' rural industry. Commentators were astonished by the magnitude and speed of privatization of TVEs. During a short period from 1995 to 2000, the vast majority of TVEs had been transferred or sold to enterprise insiders: managers and employees. Kung and Lin (2000), Park and Shen (2003), and Li (2003) investigated the reasons why such a sweeping change in property rights occurred in TVEs, a group of enterprises whose dynamic performance in the early years of reforms had both impressed and puzzled economists. The change in ideological commitment, shifts in the preference of financial institutions, and increased market competition have been identified as being among the chief factors that contributed to the massive privatization of TVEs in the late 1990s. Li and Rozelle (forthcoming) estimated the impact of 
privatization on TVE performance with a sample of 88 privatized TVEs from Jiangsu and Zhejiang for the period from 1994 to 1997 . The reform was found to have a significant positive effect on labor productivity. With a survey of 45 TVEs in Shandong and Jiangsu in 2000, Bowles, Dong and Ho (2003) found evidence that privatization had increased efficiency by making managers more responsible for the use of enterprise assets and by making firms more profit oriented.

In this paper, we examine the contrast in the experience of ownership reforms between urban SOEs and rural TVEs using a panel of industrial enterprises in Nanjing municipality for the period from 1994 to 2001. Our objectives are twofold. First, we study how the reform program of "grasp the large and let go of the small" has been carried out in practice by comparing the patterns of enterprise restructuring in the SOEs and the TVEs. Second, we investigate how the alternative reform strategy has affected firm performance in terms of the growth of labor productivity, total factor productivity (TFP), profitability, and worker earnings. We find a sharp contrast in the reform strategies of the SOEs and TVEs in two aspects. First, the changes in the SOE sector were more gradual and involved fairly limited transfer of property rights to private investors relative to the TVEs. Secondly, the reforms in both sectors exhibited selection bias but in opposite directions, with worse performing ones being the principal targets of reforms, among SOEs, and better performing enterprises being more likely to be picked for privatization, among TVEs. Our analysis discerns strikingly strong, robust positive effects of ownership restructuring on the growth of labor productivity, TFP and profitability in the reformed SOEs, indicating that the evolutionary reform policy for the SOEs has successfully reversed the trends of declining productivity and profits in these enterprises in Nanjing. We also find that among reformed urban enterprises, those in which private ownership accounts for less than $50 \%$ of shares performed better than those in which the majority of shares are owned privately. We find mixed evidence for the TVEs that privatization had no effect on firm performance in the group fixed-effects model but significant, positive effects in the firm fixed-effects model.

The reminder of the paper is organized as follows. Section 2 describes our data set and examines the difference in reform strategies between different types of public enterprises. Section 3 outlines the methodology for empirical analysis. The empirical results are reported in section 4 . Section 5 provides brief conclusions.

\section{The Data}

The data used in this present paper are derived from a survey of 168 manufacturing enterprises that was undertaken in cooperation with China's National Statistical Bureau (NBS) in the summer of 2002. The enterprises in the sample were randomly selected from those affiliated with the central, provincial and municipal governments located in Nanjing Metropolitan area and enterprises owned by 
township governments in 7 counties within the jurisdiction of the Nanjing municipal government. As the capital of one of the fast growing coastal provinces and the heartland of the rural collective sector in China_Jiangsu province-Nanjing provides a desirable sample site for comparing reform experience of urban and rural public enterprises in China. The sample of 168 firms accounts for $8.6 \%$ of the 1,963 manufacturing firms with a "designated size" of 5 million yuan or more in annual sales in Nanjing city and for $26 \%$ of the 634 public enterprises that had undergone enterprise restructuring (gaizhi) by 2002. These sample enterprises are distributed over 46 4-digit industrial branches. The data were collected through an enterprise survey and a manager survey. Using the enterprise survey we obtained information on industrial codes, ownership categories, output, sales revenue, fixed assets, equity, employment, labor compensation, intermediate inputs, investment expenditures on new technologies, and profits. The manager survey provides us with information on the privatization process and reform methods.

The enterprise panel covers the period from 1994 to 2001. The choice of 1994 as the starting date of the panel is due to the fact that China's industrial enterprises adopted a new accounting system that is more consistent with international conventions in that year, and hence the data prior to 1994 are not comparable with those in the later years. The analysis of this paper focuses on 165 enterprises the ownership categories of which prior to the reform can be identified using information obtained from the two surveys. In accordance with the ownership classification of 1994, there are 60 SOEs, 10 UCs (urban collectives), and 95 TVEs in the sample. The summary statistics presented in Table 1 shed light on the main characteristics of the three types of enterprises. Measured by the means of gross value of industrial output, net value of fixed assets, employment, and equity value, a typical SOE is substantially larger than a UC and a TVE, whereas a UC is bigger than a TVE. For instance, the average equity value of a SOE is, respectively, 26 and 56 times that of a UC and of a TVE. As mentioned in the introduction, in the absence of well-developed capital markets, privatization is more difficult for large enterprises than for small ones.

While the 165 sample enterprises were all classified by our Chinese NBS collaborators as gaizhiqiye (the Chinese term for enterprises that have undergone a system change), for an appreciable proportion of the enterprises, especially SOEs, gaizhi did not lead to any substantive change in ownership structure. To discern the scope and pace of ownership change, we derived two sets of reform indicators, the first based on the classification of each enterprise by official ownership category or type (SOEs, TVEs, etc.), and the second based on the proportions of equity owned by private individuals versus governments.

The type-based indicator of reform is defined on the basis of whether the ownership classification of an enterprise had changed, judging by the ownership code reported in the enterprise panel data and 
supplementary information from the manager survey. ${ }^{1}$ During the period of investigation 38 of the 60 SOEs changed ownership classification, with 11 becoming shareholding companies, 20 limited companies that were not wholly state owned, 5 shareholding cooperatives, and 2 private limited companies. These enterprises are defined as reformed SOEs in the empirical analysis. Of the $10 \mathrm{UCs} 3$ became shareholding cooperatives and 5 were converted to limited companies. Except for four enterprises, almost all of the 95 TVEs had changed ownership classification with 23 becoming shareholding cooperatives, 6 limited companies, and 62 private firms. Because shareholding cooperatives are usually regarded as one type of collective firms in the literature, ${ }^{2}$ only those UCs and TVEs that had been transformed into limited liability companies or private firms are classified as reformed ones in our empirical investigation.

The second set of reform indicators that we use is derived from information on equity ownership obtained from the enterprise panel. Because the sample size of UCs is small and the ownership structure of UCs is more similar to that of SOEs than TVEs, SOEs and UCs are combined as one group which we call "urban enterprises." Each group is then divided into three classes: 100\% publicly-owned, partially privatized but publicly-controlled (i.e., public ownership still exceeds 50\%), and privately-controlled firms (i.e., private ownership is between 50 and $100 \%$ ).

Table 2 presents summary statistics of the reform indicators. These statistics reveal sharp contrasts in the scope and pace of change between different types of public enterprises. Specifically, the reform process began earlier but proceeded more slowly in the SOEs and UCs than in the TVEs. Based on the indicators of ownership-category shift, 10 to 13 percent of the UCs and SOEs had already undergone substantive restructuring by 1994 , but the proportion only rose to 50 to 63 percent in 2001 . By contrast, the change did not begin in the TVEs until 1996; however, nearly three quarters of the enterprises had been converted into partially privatized limited companies or wholly privately owned firms by 2001 . Moreover, compared with the rural TVEs, the scope of privatization for the two types of urban public enterprises was fairly limited. By 2001, on average only $25.4 \%$ of the equity of the urban enterprises was owned by private investors, and the firms that became privately controlled only accounted for $16.7 \%$ of

1 The ownership code of the data uses a four-category classification for the period from 1994 to 1997 and a 23-category classification for the period from 1998 to 2001. The information from the manager survey was used to help identify the ownership category of a few enterprises that had changed ownership prior to 1994.

${ }^{2}$ For example, see Jefferson, et. at. (2003). Theoretically, shareholding cooperatives are the enterprises in which dividends are distributed according to share ownership but major decisions are made based on the principle of one member one vote. It has been reported that some privatized TVEs that did not meet this criterion were also registered as shareholding cooperatives (Ho, Bowles and Dong, 2003). However, by excluding shareholding cooperatives from reformed UCs and TVEs we are able to focus on the impact of transformation of collective enterprises into conventional firms. 
these enterprises. In contrast, private investors owned $68.9 \%$ of the equity and controlled $72.9 \%$ of the rural TVEs in the sample.

While both urban and rural enterprises were privatized primarily to enterprise insiders, i.e., managers and employees, the distribution of equity ownership over private investors was more skewed towards managers in the reformed rural enterprises than in their urban counterparts. In contrast to the growing managerial ownership concentration observed among privatized rural enterprises, the proportion of private equity owned by employees in the urban enterprises was rising over time; the distribution between managers and employees became more or less equally split by 2001. It is noteworthy that the governments at both the township level and the levels above appear to be revenue conscious in that the privatization of both urban and rural enterprises did not entail substantial free transfers of public assets as observed in many countries in Eastern Europe. The managers and employees in both sectors were, on average, expected to pay 76 to 88 percent, respectively, of the value of the shares they acquired, ${ }^{3}$ and 73 to 94 percent of these inside private investors paid, respectively, the full amount due up front. Judging by the proportion of the purchase price paid up front, the transformation of ownership from the government to private investors seems to be more complete with the employee shareholders than the managers and more thorough in the urban enterprises than the rural TVEs. Having inside private investors pay for their share acquisition is not only more desirable for state revenues but also likely to have stronger incentive effects, compared with the scheme of free transfers. ${ }^{4}$

Having reviewed the striking difference in the approach to enterprise restructuring between different types of public enterprises, we now turn to our investigation of how the reform affected enterprise performance across ownership types. We examine four aspects of firm performance: labor productivity, total factor productivity (TFP), profits per unit of fixed assets, and worker earnings. TFP and profitability provide comprehensive measures of performance in terms of technical and economic efficiency. Labor productivity is introduced as a more partial indicator of productivity which is particularly sensitive to changes in the workforce and capital stock. While labor productivity, TFP and profitability measure enterprise accomplishment in efficiency, the analysis of earnings sheds light on the impact of privatization on workers. We measure labor productivity by two indicators: value-added per worker and sales revenues per worker. Value-added and sales revenues are both converted to 1994 constant RMB using the ex-factory price index of industrial products as the deflator. A TFP index is

\footnotetext{
${ }^{3}$ The value of a sample firm was determined by two main methods: negotiation between the government and the enterprise and assessment by an outside evaluator. External evaluation accounted for about 82 and $91 \%$ of the sample SOEs and UCs and $48 \%$ of the sample TVEs.

${ }^{4}$ Using the ratio of the up front payment to the value of the shares acquired at the time of privatization as a measure of the completeness of ownership transfer, Li and Rozelle (forthcoming) found that the ratio is positively correlated with labor productivity of privatized TVEs.
} 
derived with the assumptions that a Cobb-Douglas production function adequately describes the firms' technology and that the factor share is 0.6 for labor and 0.4 for capital. In the calculation, output is measured by gross value of industrial output (GVIO); labor is the number of employees at year-end; and capital is net value of fixed assets (NVFA). GVIO is also measured in 1994 RMB using the same price deflator as for value-added and sales revenues. The real value of NVFA is calculated using the recursive method developed by Jefferson, et. al.(1992) and the price index of investment in fixed assets. As a measure of profitability, we look at total profits divided by original value of fixed assets. Our earnings measure is the average annual earnings of production workers, which consist of wages, bonuses and dividends, and is deflated by the consumer price index with 1994 as base year. All the price deflators are obtained from China's Statistical Yearbook.

Table 3 presents the summary statistics of the annual rates of growth of labor productivity, TFP, and worker's earnings and the level of profits per unit of assets for the enterprises in our sample over the period from 1994 to $2001 .^{5}$ The statistics reported in part I of the table are computed over six enterprise groups divided by the indicators of ownership-category shift mentioned before. Comparing the three types of unreformed public enterprises, we observe a familiar ranking of performance, that is, urban public enterprises, i.e., SOEs and UCs, were trailing behind rural TVEs by most efficiency measures. A comparison between the reformed and the unreformed enterprises in each sector indicates that the prereform performance records of the eventually reformed SOEs and UCs were noticeably worse than that of their counterparts that were not later reformed, whereas the pre-reform gap between later reformed and unreformed TVEs in most measures was negligible. The performance of both reformed SOEs and TVEs appears to have improved in the post-reform period, but the magnitude of change in the reformed SOEs was more striking, with a sharp reverse of the trends of declining labor productivity, TFP and workers' earnings and a turnaround from the money-losing situation. However, the restructuring seems to have failed to stop the further deterioration of performance for UCs in the post-reform period.

Part II of Table 3 reports summary statistics for the enterprise groups that eventually exhibited different degrees of privatization. As with the reformed SOEs and UCs, the two types of urban enterprises that were eventually partly or mainly privatized appear to be among those enterprises with worse performance records within the sector, compared with the urban enterprises that were to remain $100 \%$ publicly owned. By contrast, the eventually privatized rural TVEs were, on average, more productive and more profitable prior to the privatization than the TVEs that were to remain $100 \%$ owned by local

\footnotetext{
5 The annual rates of growth of labor productivity, TFP and worker earnings are calculated as the difference in the value of the variable in $\log$ form between periods $t-1$ and $t$. We report the level instead of growth rate for profits because this variable has a large number of observations with negative values. As with most firm-level databases, the values of some variables in our data set fluctuate widely, despite our strenuous efforts to clean up the data.
} 
governments. Regarding the post-privatization performance, resembling the reformed SOEs, the urban enterprises that were partially privatized but remained publicly controlled displayed remarkable improvement of performance by all measures. The post-privatization records of the majority private urban enterprises were mixed, with lower rates of growth in labor productivity and TFP and faster growth in worker earnings and higher rate of profits. Like the reformed TVEs defined on the basis of ownershipcategory shift, both types of privatized rural enterprises failed to register significant post-reform improvement by most indicators. However, it is inappropriate to draw inferences concerning the performance-ownership relationship from these summary statistics alone, since the patterns revealed by these statistics may be attributable to many factors. The impact of these factors is next studied by econometric analysis.

\section{Econometric Specification}

The central question of this paper concerns the effects of ownership restructuring on firm performance by different type of reformed public enterprises. Specifically, we wish to investigate if the reform had stronger positive effects in the rural sector than in the urban sector, as the change in the former was accompanied with more rapid and more extensive transfer of property rights to private investors and a higher degree of ownership concentration in the hands of managers than that in the latter. One main obstacle to an accurate assessment of reform effects is possible selection bias. As indicated by the descriptive statistics presented in Table 3, firm performance may have been a determining factor in which firms were picked for restructuring and by what method. A reverse causality between performance and the choice of ownership type generates biased and inconsistent estimates.

To address the concern about selection bias, we assess the effects of enterprise restructuring on firm performance using two versions of the panel data treatment model (Frydman, et. al., 1999). In this framework, reform is expressed as the treatment variable and possible selection bias is controlled as group- or firm-specific fixed effects. The same two sets of reform variables and group classifications are adopted in this analysis as in Section 2, that is one based on change in ownership code and the other on the scope of private equity ownership. To obtain consistent estimates of reform effects, we also control for other factors that may affect post-reform performance, such as initial conditions, macroeconomic environment, market structure of industrial branches, and access to credit markets. The control for these factors is particularly important for a proper comparison of reform effects between the rural and the urban enterprises. For instance, due to the law of diminishing returns, reformed SOEs and UCs may register higher rates of growth than reformed TVEs simply because they were less productive prior to the reform. Moreover, the assessment of post-reform performance could be less favorable to TVEs than SOEs and UCs due to the fact that the majority of the TVEs were privatized after 1997 when China's economy 
experienced a recession following the Asian Financial crisis, whereas the number of reformed urban enterprises was distributed more evenly over the period of investigation. Furthermore, the skewed sectoral distribution with SOEs being more concentrated in protected sectors and TVEs more in competitive sectors may lead to inflated performance effects for SOEs relative to TVEs. Lastly, it has been well recognized that state enterprises have better access to bank loans relative to non-state enterprises. ${ }^{6}$ The difference in the ability to obtain credit can also lead to differentiated effects on firm performance. Thus, the efforts to control for the differences in initial conditions, the timing of reform, the distribution over industrial branches, and access to bank loans help to minimize downward bias against TVEs in the assessment.

In our analysis, firm performance is measured by the growth instead of the level of each performance indicator. Annual rates of growth, defined as the difference in the value of the variable in $\log$ form between periods $\mathrm{t}-1$ and $\mathrm{t}$, are derived for two proxy variables for labor productivity, TFP and worker earnings. The growth of profitability is measured as change in the value of profits (not in $\log$ form) between the two periods because a large number of observations have negative values. These growth measures difference away any fixed firm specific attributes that affect the level of performance indicators, making the estimates more robust to unobservable characteristics.

We begin with the group-specific fixed effects model. Let $i, i=1,2 . . N$, denote firms, $j, j=1,2 \ldots J$ denote ownership type, $\mathrm{t}, \mathrm{t}=1,2 . . \mathrm{T}$ time period, $\mathrm{k}, \mathrm{k}=1,2 \ldots \mathrm{K}$ industrial branch. A reduced form growth model is specified as follows:

$$
y_{i t}=\alpha_{0}+\sum_{J-1} \alpha_{j} D_{j i}+\sum_{J-2 o r 3} \beta_{j} R_{j i t}+\gamma X_{i t-1}+\sum_{T-1} \delta_{t} Y E A R_{i t}+\sum_{K-1} \theta_{k} I N D_{k i}+\eta L O A N_{t-1}+u_{i t}
$$

In this model, $y_{i t}$ is the rate of growth of labor productivity, TFP, or worker earnings (the change of profitability) for firm $\mathrm{i}$ between $\mathrm{t}-1$ and $\mathrm{t}$. $\mathrm{D}_{\mathrm{ji}}$ is a time-invariant dummy variable equal to one if the firm $\mathrm{i}$ is registered as ownership type $\mathrm{j}$ in the last period of investigation and zero otherwise; $\mathrm{R}_{\mathrm{jit}}$ is the reform variable equal to one if firm $i$ operates as ownership type $j$ in period $t$ and zero otherwise. $X_{i t-1}$ is the level of a given performance indicator (in log form for labor productivity, TFP and earnings and linear form for profits) at period $\mathrm{t}-1$, which measures the initial condition of firm $\mathrm{i}$. Year ${ }_{\mathrm{it}}$ and $\mathrm{IND}_{\mathrm{ki}}$ are the time and industrial branch dummy variables which are introduced to control for differences in the macroeconomic

\footnotetext{
${ }^{6}$ The bank reform starting in 1994 that has substantially reduced the influence of township and village government on credit allocation has been regarded as one of the main factors contributing to the demise of TVEs in the later 1990s (Park and Shen, 2002). Privatization, however, has made bank loans even more inaccessible to rural enterprises. Using the data on banks and TVEs in Jiangsu and Zhejiang, Brandt and $\mathrm{Li}$ (2003) find that both private firms and privatized TVEs were about $50 \%$ and $25 \%$ less likely to obtain a loan than township enterprises and that the loans obtained by private or privatized firms were considerably smaller than were those obtained by TVEs that remained under local government ownership.
} 
environment and market structure. LOAN is amount of loans per worker lagged by one period (its summary statistics are reported in Table 1). $u_{i t}$ represents the random disturbances of the model.

The parameters, $\beta_{\mathrm{j}}$, measuring the treatment effects, i.e. the impact of a shift to ownership type $\mathrm{j}$ on firm performance, are the focus of our analysis. The fixed group effects, $\alpha_{j}$, capture the difference in performance between ownership types due to unobservable group-specific characteristics. With the reform effects being controlled for, $\alpha_{j}$ for a reformed category represents the pre-reform performance of the firms in that group relative to the omitted group, which is the unreformed SOEs in the regressions using ownership code indicators and the urban enterprises under $100 \%$ public ownership in the regressions with ownership dummies defined by degree of private ownership. Using the estimates of $\alpha_{j}$ we test whether pre-reform performance played a role in selecting firms for restructuring in general or restructuring to particular types of ownership.

Although the group fixed-effects model has the advantage of permitting some inferences to be drawn regarding the pre-reform performance of firms subsequently restructured (Earle and Telegdy, 2001), this specification imposes a strong assumption that the firms within each group have similar unobserved characteristics associated with performance outcomes. This assumption may be implausible for an investigation involving a long reform process like the present one, because firms that were privatized earlier may possess different unobserved characteristics than those privatized in the later stage of the reform. To eliminate possible selection bias stemming from unobserved firm-specific characteristics correlated with performance outcomes, we estimate the reform effects on firm performance with a firm fixed-effects model. This model is specified as

$$
y_{i t}=\alpha_{i}+\sum_{j} \beta_{j} R_{j i t}+\gamma X_{i t-1}+\sum_{t} \delta_{t} Y E A R_{i t}+\eta L O A N_{t-1}+u_{i t}
$$

where $\alpha_{i}$ is a firm specific fixed effect which controls for selection bias as well as observable timeinvariant attributes such as market structure.

Equations (1) and (2) are estimated by OLS. A shortcoming of this estimation technique is that it assigns large weights to sample outliers, making the estimates sensitive to measurement error. Noticing that our data are quite noisy, we also estimated equation (1) with the robust OLS method, which downweights outliers, to check the robustness of the estimates. Since the results of robust OLS are substantively similar to those of OLS, only the OLS estimates are reported for the sake of streamlining the exposition. ${ }^{7}$ Moreover, notwithstanding our efforts to control for selection bias, the fixed-effects model can only address such bias stemming from time-invariant unobservable attributes associated with performance. Selection bias could be generated by a dynamic process in which the possibility of a firm

\footnotetext{
${ }^{7}$ The computer software for robust OLS applied for firm fixed effects models is not available, so we are unable to apply this technique to equation (2).
} 
being picked for restructuring or being restructured into a particular ownership type is correlated with the firm's potential to raise rates of growth in the future. We are unable to test if the model is subject to this type of simultaneous bias in this study. Controlling for this type of dynamic selection bias requires that there be instrumental variables that are correlated with ownership change but not with the growth of a performance indicator. Unfortunately, our data do not contain such variables.

\section{Empirical Results}

Tables 4 and 6 present, respectively, OLS estimates of equations (1) and (2) for all five performance measures, with $4 \mathrm{a}$ and $6 \mathrm{a}$ for the regressions based on ownership-category shift and $4 \mathrm{~b}$ and $6 \mathrm{~b}$ for the regressions on degrees of privatization. As indicated by F statistics presented at each table, all the growth regressions are highly significant with p-value approaching to zero. Although the coefficients on reform variables are the primary interest of our analysis, we first examine the estimates of those variables controlling for the initial condition, access to bank loans, and macroeconomic environment. ${ }^{8}$ As expected, the initial level of performance for all measures has a significantly negative coefficient in all runs, displaying a salient trend of convergence in performance among sample firms. Also consistent with economic intuition, the estimates for loan per worker indicate that access to bank credit has significantly positive effect on the growth of value-added per worker, revenues per worker, and TFP, but has no significant impact on profits in all the regressions. Regarding the impact of bank credits on worker earnings, the two regression models generate different results, with significantly positive estimates obtained from the group fixed-effects model and insignificant ones from the firm fixed-effects model.

The estimates of year dummy variables document a positive trend of growth in labor productivity, TFP and worker earnings over the period of investigation. However, these estimates report no significant improvement in financial performance over the sample period and a significant fall in profits in 1997 when the economy was adversely affected by the Asian financial crisis. The stagnation of profitability in the face of rising productivity has been a general pattern for China's state industry following the large scale of enterprise downsizing in the late 1990s (Dong, 2003). The labor retrenchment has increased sharply productivity of SOEs but led to only moderate improve in their financial records as viable SOEs were still responsible for 30 to 100 percent of the expenditures of supporting xiagang workers and internally retired employees. After reviewing the estimates of the aforementioned controlling variables, in the remaining section, we examine the patterns of selection bias and the impact of reforms on firm performance. 


\section{$\underline{\text { Selection Bias }}$}

We begin with the estimates of group effects reported in Tables $4 \mathrm{a}$ and $4 \mathrm{~b}$. The F statistics presented at the bottom of each table reject the hypothesis of zero group effects at the $5 \%$ level or higher in all the regressions. Part of group heterogeneity in performance is attributable to the longstanding gap between different types of public enterprises. As indicated by the estimates, the growth of TFP and profitability is significantly higher in the rural TVEs than the urban SOEs and collectives, whereas a reversed pattern of growth gap in worker earnings between the two sectors is observed. Within the urban sector, compared with the unreformed SOEs (i.e., SOEs that were not to be reformed by 2001), the unreformed UCs are significantly more profitable, and both the reformed and unreformed UCs have lower rates of growth in worker earnings.

While these results are reassuring, our primary interest in group effects is to test if pre-reform performance has been a determinant of the reform policy regarding which firm is selected for restructuring or being transformed to a particular type of ownership. ${ }^{9}$ From the group effects estimates, we calculate the performance gap between the firms with different reform status or ownership structure and present these estimates and their $\mathrm{t}$ statistics in Table 5. From the estimates derived from the reformeffects regressions, we notice that the SOEs and UCs that were picked for reform appear to be among the firms with worse pre-reform performance records within the sector. Evidently, the pre-reform rates of growth are significantly lower $(-12.3 \%$ in revenue per worker and $-4.6 \%$ in worker earnings) for SOEs subsequently reformed relative to those never reformed; a significant lower growth of profits per unit of assets $(-5 \%)$ is observed for the eventually reformed UCs prior to the restructuring. By contrast, there is no significant pre-reform performance gap in any efficiency measure between the reformed and unreformed TVEs, although the pre-reform growth in worker earnings is significantly higher for the reformed TVEs compared with those unreformed.

The indications that the ownership reform in the urban sector was targeting the worse performing firms are supported by the statistics obtained from the private-ownership-effects regressions. The estimates on the group dummy for urban public controlled (i.e., minority privatized) enterprises, significant at the 5\% level, imply that the pre-privatization growth of those firms is lower by $16.5 \%$ in value-added per worker, by $20.2 \%$ in revenues per worker, by $14.8 \%$ in TFP and by $4.9 \%$ in earnings than the growth in the enterprise that remained $100 \%$ publicly owned. The pre-reform growth is also

\footnotetext{
8 The estimates of industrial branches are omitted from the discussion for the sake of streamlining the exposition.

${ }^{9}$ Recall that group status for different type of public enterprise is determined at the beginning of the sample period, and that we assign enterprises that are found to have undergone privatization and those that did not, as of the end of the sample period, to different groups in order to investigate possible differences leading to subsequent selection.
} 
significantly lower for those urban enterprises that subsequently become majority privately owned than for the never privatized urban enterprises by all measures, but only the estimate of -0.89 for worker earnings is statistically significant. The pre-reform records of the majority privately owned enterprises in labor productivity and TFP are slightly better than those of the minority privatized enterprises, but the differences are statistically insignificant. Comparing the two types of eventually privatized TVEs with those remaining $100 \%$ publicly owned, we notice that the privatized TVEs have higher growth in most performance measures but the gap is significant only for revenues per worker.

In studies of privatization in Eastern Europe, the authors often find either no evidence of ownership-related bias in the selection of firms for privatization (Frydman, et. al., 1999) or, if there is a bias, that it is firms with higher pre-privatization growth that tend to be picked for privatization (Earle and Teledgy, 2001), as is found to be the case for rural firms in the present study. Our finding that reformed urban enterprises tended to be among those with lower pre-reform productivity growth therefore calls for some comment. One possible explanation is that the revenue-conscious governments face a more binding wealth constraint on the part of the buyers when privatizing productive, large enterprises than when selling non-productive or small enterprises. Another possibility is that, unlike in post-Communist Eastern European countries where the authorities are fully committed to creating a private-enterprise economy, those overseeing the state sector in China want to keep the best enterprises in state hands, and they thus begin privatization by targeting those enterprises that have been performing most poorly. Recall that the ownership restructuring of China's public sector is introduced with the intention of maintaining state ownership for large enterprises and privatizing only small- and medium-size ones, as described by the slogan of "grasp the large and let go of the small". A third explanation is perhaps that privatization may meet stronger and more effective resistance from urban workers than rural workers (Dong, 2003). Unlike TVE workers, workers in SOEs and large urban collectives are entitled to job security and welfare benefits, such as medical care and retirement pensions. However, the urban workers' entitlements are closely linked to the financial situation of the firm. The costs of privatization to workers in the moneylosing enterprises are relatively low because these firms had already experienced great difficulty to pay workers on time, reimburse medical expenses, and meet their obligations to contribute to pension funds prior to the restructuring. Thus, these workers are likely to be more supportive of privatization than their counterparts in better performing public firms in the urban sector.

\section{Reform and Firm Performance}

We first look at the estimates of reform effects for the group fixed-effects regressions. The estimates presented in Table 4a indicate that ownership restructuring has positive effects on the performance of reformed SOEs by all four efficiency measures with each estimate being significant at the $1 \%$ level. According to the point estimates, quantitatively, the ownership reform has raised the annual 
rate of growth by $25.6 \%$ for value-added per worker, $19.2 \%$ for sales revenues per worker, $27.6 \%$ for TFP, and the annual growth of profits per unit of assets by $3.1 \% .{ }^{10}$ These strikingly large estimates are compatible with findings of some empirical studies on transition economics. For instance, Frydman et. al., (1999) reported that privatization increased the annual rate of growth of revenues per worker by $16.4 \%$ for the firms that were privatized to private financial institutes in the Czech Republic, Hungary, and Poland. Earle and Telegdy (2001) estimated that the annual rate of growth in labor productivity in the firms privatized to foreign investors increased by $19.1 \%$ in the post-privatization period in Romania. In contrast to the remarkable positive estimates obtained for the state sector, none of the estimates on efficiency indicators for the urban collectives and the rural TVEs are found to be statistically significant. The enterprise restructuring does not have significant impact on the growth of worker earnings for any of the three sectors.

While the estimates presented in Table 4a shed light on average effects of ownership reforms for each type of public enterprises, the regression results in Table $4 \mathrm{~b}$ permit inferences to be drawn regarding the relationship between the proportion of ownership in private hands and firm performance. These estimates document positive, significant effect of the shift from wholly public ownership to majority public ownership in the urban sector on all performance measures. The point estimates imply $26.0 \%$ higher growth in value-added per workers, $23.9 \%$ in revenues per worker, $26.6 \%$ in TFP, and $6.1 \%$ in worker earnings, and $3.4 \%$ in profits per unit of assets for the urban enterprises that shifted to partial but not majority private ownership relative to their pre-privatization performance, with all the estimates significant at the $5 \%$ level or higher. ${ }^{11}$ By contrast, the estimates of privatization effects on all four efficiency measures are insignificant for the urban enterprises that reached or exceeded the threshold of $51 \%$ private ownership and for both types of privatized rural enterprise regardless of whether they remained predominately owned by the local government or came under majority ownership by private investors. However, except for the rural enterprises under majority private ownership, the postprivatization growth of worker earnings is significantly higher, $6.1 \%$ for those urban enterprises under minority private ownership, $8.7 \%$ for majority privately owned urban enterprises, and $6.7 \%$ for the majority publicly owned rural enterprises.

The results presented in Tables 4 control for selection bias at the group level. As mentioned earlier, the group specific fixed effects model does not control for selection bias resulting from the

\footnotetext{
${ }^{10}$ The point estimates by robust OLS regressions are somewhat smaller, $9.0 \%$ for value-added per worker, $11.5 \%$ for revenues per worker, $9.5 \%$ for TFP, 1.0 percentage point for profits per unit of assets, and $3.8 \%$ for earnings. All the estimates are significant at the $10 \%$ level or higher.

${ }^{11}$ The point estimates pf robust OLS for this specification are again smaller, 0.117 for value-added per worker, 0.110 for revenues per workers, 0.141 for TFP, 0.039 for earnings, and 0.004 for profits; except for profits, all the estimates are significant at the $5 \%$ level.
} 
heterogeneity in unobservable productive attributes within the group. The estimates of the firm specific fixed-effects model reported in Tables $6 \mathrm{a}$ and $6 \mathrm{~b}$ eliminate the possibility of this type of selection bias. As indicated by the F statistics presented at the bottom, all the regressions are highly significant, and the hypothesis of zero firm-specific fixed effects is rejected for every equation. Consistent with those for group-level controls, the estimates show that the ownership reform has significant, positive effects on the growth in value-added per worker $(27.1 \%)$, revenues per worker $(14.8 \%)$, TFP $(32.9 \%)$ and profits per unit of assets (3.8\%) for the SOEs, and that the post-privatization growth in those partially privatized but still majority publicly owned urban enterprises is significantly higher, $17.8 \%$ for value-added per worker, $19.8 \%$ for revenues per worker, $20.7 \%$ for TFP, $4.7 \%$ for profits, and $6.8 \%$ for worker earnings. The results of the firm fixed effects regressions also show once again that the shift from wholly public ownership to one dominated by private investors does not have any significant impact on performance among urban enterprises. However, the firm fixed effects model provides a different assessment of reform effects for the UCs and the TVEs. With those statistically significant estimates, the regressions document lower post-reform growth in value-added per worker and TFP for the reformed UCs. These estimates also show higher post-reform growth in TFP (14.4\%) and profits (2\%) for the reformed TVEs, higher growth in revenues per worker $(15.1 \%)$ for the partially privatized but still majority publicly owned rural enterprises, and higher growth in TFP (10.8\%) and in profits (2.1\%) for rural enterprises that became majority privately owned. The magnitude of these effects in the TVEs are, however, small relative to those in the reformed SOEs and those for the public controlled urban enterprises.

\section{Conclusions}

In this paper, we've taken a preliminary look at ownership reform in both urban and rural enterprises in and around Nanjing municipality using data specifically collected for this purpose from 168 enterprises covering the years 1994 to 2001 . We've focused both on the effects of ownership change on performance as measured by growth rates of productivity, profits and worker earnings, and on differences in pre-reform performance between firms selected and those not selected for privatization. Our results conform with expectations in that they show the shift towards more private forms of property rights to be associated with improvements in performance outcomes in most cases.

Our results are unexpected and noteworthy in two main respects. First, we've found that whereas among rural enterprises, it was the better pre-reform performers that tended to be selected for privatization, among urban enterprises this situation is reversed. The latter outcome differs from what is

found in transition economies in Eastern European. Second, we've found that among reformed urban enterprises, those in which private ownership accounts for less than $50 \%$ of shares performed better than 
those in which the majority of shares are owned privately. There is, it seems, a U-shaped relationship between the degree of privatization and the level of performance.

Perhaps both findings are related to the more gradual—one might alternatively say more reluctant and incomplete - nature of SOE privatization in China as compared to the no longer Communist-ruled transition economies. Provincial and municipal government officials in Nanjing may be in no rush to privatize well-performing state enterprises. And enterprises with substantial public ownership may still have privileged access to certain resources in China's semi-reformed environment, making mixed ownership still superior to either fully private or fully public ownership. The paucity of large concentrations of funds in private hands with which to purchase successful urban enterprises, when combined with the authorities' unwillingness to sell off firms at sharply slashed prices or to lauch voucher schemes, may also help to explain the earlier privatization of weaker rather than of stronger urban enterprises in our sample.

The smaller scale of many rural firms may mean that in the rural sector, insider privatization is feasible even for more successful enterprises. Perhaps township and village officials and enterprise managers also have closer personal and family ties in rural than in urban areas. Officials deciding which rural enterprises to privatize have a greater likelihood of being direct personal beneficiaries of privatization - i.e., they will be among, or in the immediate circle of, the owners - while for urban officials the main effect of privatization may be a loss of personal power.

Our data set is unusually rich in information about the distribution of ownership stakes both immediately after ownership change, and after passage of a few years. In future research, we hope to look more directly at the causes and consequences of differences in the degree of insider versus outsider ownership, and in the degree to which ownership is spread among both managers and workers or is concentrated in the hands of managers, especially top managers. Among the questions to be investigated is whether there is evidence of more widely shared forms of ownership, profit-sharing, and control rights within privatized rural or urban enterprises, and whether enterprises exhibiting such forms of worker participation exhibit systematic differences in productivity, wages, and employment outcomes. 


\section{Reference}

Alexeev, Michael, "The Effect of Privatization on Wealth Distribution in Russia." Economics of Transition, 7, 2: 449-465, July 1999.

Black, Bernard, Reinier Kraakman and Anna Tarassova, 2000, "Russian Privatization and Corporate Governance: What Went Wrong?” Stanford Law Review, 52,6:1731-1809.

Bowles, Paul, Xiao-yuan Dong and Samuel Ho, "Managerial Autonomy, Firm Objectives and the Role of Local Governments in Post-Privatization Rural China: Some Survey Evidence." Journal of Asian Business, 18(3): 17-30, 2002.

Brandt, L. and Li, Hongbin, "Bank Discrimination in transition economics: ideology, information, or incentives?” Journal of Comparative Economics, 31, 3: 387-413, September 2003.

Dong, Xiao-yuan, “China's Urban Labor Adjustment: A Literature Review” working paper, East Asia Human Development Sector Unit, World Bank, June 2003.

Eale, J and Almos Telegdy, 2001, "Employee Ownership after Privatization: Governance Institutions and Firm Performance in Romania." Working paper, Upjohn Institute for Employment Research, Central European University.

Frydman, Roman, Cheryl Gray, Marek Hessel and Andrzej Rapaczynski, 1999, "When Does Privatization Work? The Impact of Private Ownership on Corporate Performance in the Transition Economies." Quarterly Journal of Economics, 114, 4: 1153-1191.

Garnaut, Ross, Ligang Song, Stoyan Tenev, and Yao, Yang, A Study of Firm Restructuring in China. Washington, D.C.: The World Bank, 2003.

Gray, Cheryl W., "In Search of Owners: Privatization and Corporate Governance in Transition Economies." The World bank Research Observer." 11, 2: 179-197, August 1996.

Ho, Samuel, Paul Bowles, and Xiao-yuan Dong, "Letting Go of the Small: An Analysis of The Privatization of Rural Enterprises in Jiangsu and Shandong." Journal of Development Studies, 39(4): 1-26, April 2003.

Jefferson, Gary H., Albert Guangzhou Hu, Xiaojing Guan and Xiaoyun Yu, 2003, "Ownership, Performance, and Innovation in China's Large and Medium-Size Industrial Enterprise Sector." China Economic Review 14(1): 89-113.

Jefferson, Gary H., Rawski, Thomas G. and Yuxin Zheng, "Growth, Efficiency, and Convergence in China's State and Collective Industry." Economic Development and Cultural Change, 40, 2: 239-266, January 1992.

Kung, James K.S. and Yi-min Lin, 2000, “The Evolving Ownership Structure in China's Economic Transition: An Analysis of the Rural Non-farm Sector." Working paper.

Li, Hongbin, "Government's Budget Constraint, Competition, and Privatization: Evidence from China's Rural Industry." Journal of Comparative Economics, 31,3: 486-502, September 2003. 
Li, Hongbin and Scott Rozelle, "Insider Privatization with a Tail: The Screening Contract and Performance of Privatized Firms in Rural China." forthcoming in Journal of Development Economics.

N.B.S, China’s Statistical Yearbook 2000, Beijing: China's Statistics Press.

Park, Albert and Shen, Minggao, "Joint Liability Lending and the Rise and Fall of China's Township and Village Enterprises." forthcoming in Journal of Development Economics.

Roland, Gerard, 2002, "The Political Economy of Transition." Journal of Economic Perspectives,16, $1: 29-50$.

Svejnar, Jan, "Transition Economics: Performance and Challenges." Journal of Economic Perspectives, 16, 1: 3-28, Winter 2002.

Sun, Qian, Tong, Wilson H. S. and Tong, Jing, "How Does Government Ownership Affect Firm Performance? Evidence from China's Privatization Experience." Journal of Business Finance \& Accounting, 29, (1/2): 1-27, January 2002.

Yao Yang and Song, Ligang, "Impact of privatization on Firm Performance in China." Working paper, China's Center of Economic Research, Beijing University, 2003. 
Table 1: Main Characteristics of SOEs, UCs, and TVEs

\begin{tabular}{|c|c|c|c|}
\hline & SOEs & Urban collectives & TVEs \\
\hline \multicolumn{4}{|l|}{ GVIO (million yuan) } \\
\hline Mean & 487.54 & 32.66 & 23.12 \\
\hline $\begin{array}{l}\text { Standard deviation } \\
\text { NVFA (million yuan) }\end{array}$ & $1,474.52$ & 44.50 & 31.17 \\
\hline Mean & 306.47 & 7.07 & 4.03 \\
\hline Standard deviation & $1,044.94$ & 9.31 & 6.86 \\
\hline \multicolumn{4}{|l|}{ Employment (workers) } \\
\hline Mean & 2,925 & 430 & 217 \\
\hline $\begin{array}{l}\text { Standard deviation } \\
\text { Equity }\end{array}$ & 5,052 & 378 & 208 \\
\hline Mean (million yuan) & 177.57 & 6.82 & 3.16 \\
\hline Standard deviation & 592.46 & 9.77 & 5.83 \\
\hline \multicolumn{4}{|l|}{ Loan per worker } \\
\hline Mean ( 1,000 yuan) & 23.5 & 3.2 & 4.6 \\
\hline Standard deviation & 54.9 & 12.1 & 12.3 \\
\hline No. of firms & 60 & 10 & 95 \\
\hline
\end{tabular}

Notes: The statistics presented in this table are derived from the enterprise panel data set. 
Table 2: Summary Statistics of Ownership Reforms

Distribution of sample firms by ownership categories: ${ }^{1}$

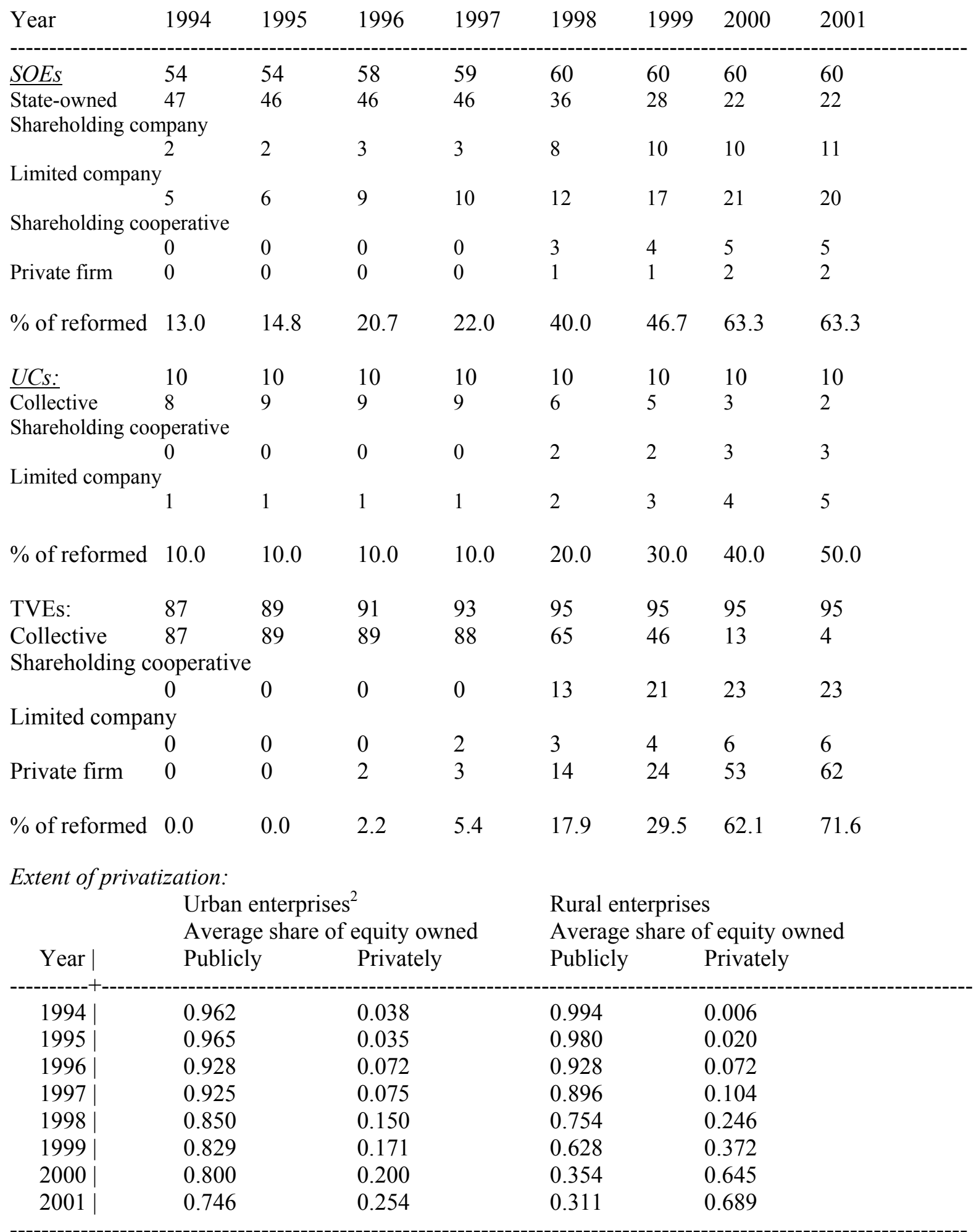


Table 2: Summary Statistics of Ownership Reforms (continued)

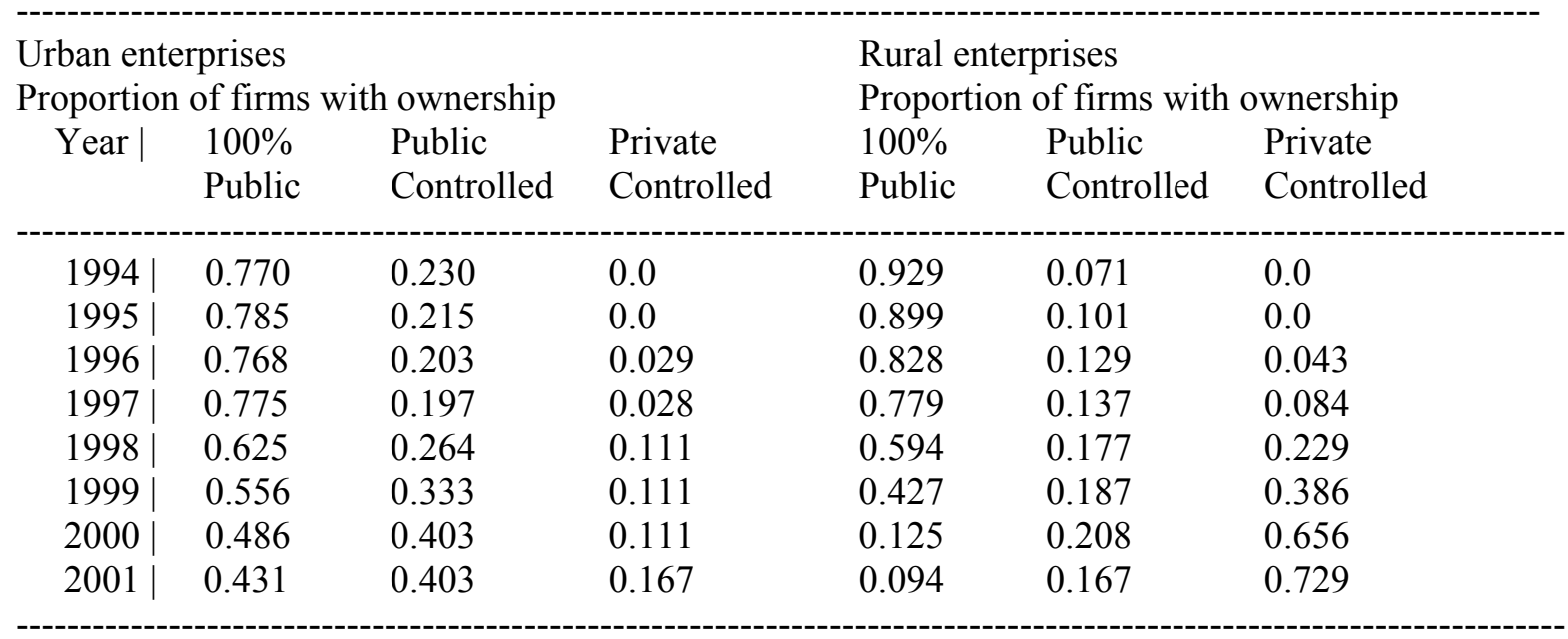

Distribution of private ownership ${ }^{3}$

Urban Enterprises Rural Enterprises

Management Employees Outsiders Management Employees Outsiders

\begin{tabular}{rrrrrrr}
\multicolumn{2}{r}{ Right after reform } \\
In 2001 & 0.416 & 0.218 & 0.366 & 0.531 & 0.179 & 0.289 \\
& 0.369 & 0.337 & 0.294 & 0.613 & 0.162 & 0.225
\end{tabular}

Payments by inside private investors

Urban enterprises

Management $\begin{array}{ll}\text { Employees } & \text { Rural enterprises } \\ \text { Management }\end{array}$

Management Employees

Payment expected as \% of the value of share they owned
$76.05 \%$
$88.01 \%$
$86.19 \%$
$83.72 \%$

Payment arrangement:

Proportion of the investors paying a lump sum up front
$80.48 \%$
$93.55 \%$
$73.33 \%$
$86.20 \%$

Notes: 1. A firm is defined as reformed if the firm has undergone restructuring to the extent that it leads to a substantive change of its ownership code by China's National Statistical Bureau.

2. Urban enterprises include SOEs and UCs. The two types of urban public firms are combined because the sample size of collectives is small and the two types of firms are similar in terms of extent of privatization.

3. The statistics presented prior to this part of Table 2 are obtained from the enterprise panel data and those reported in the remaining table are from the manager survey. 


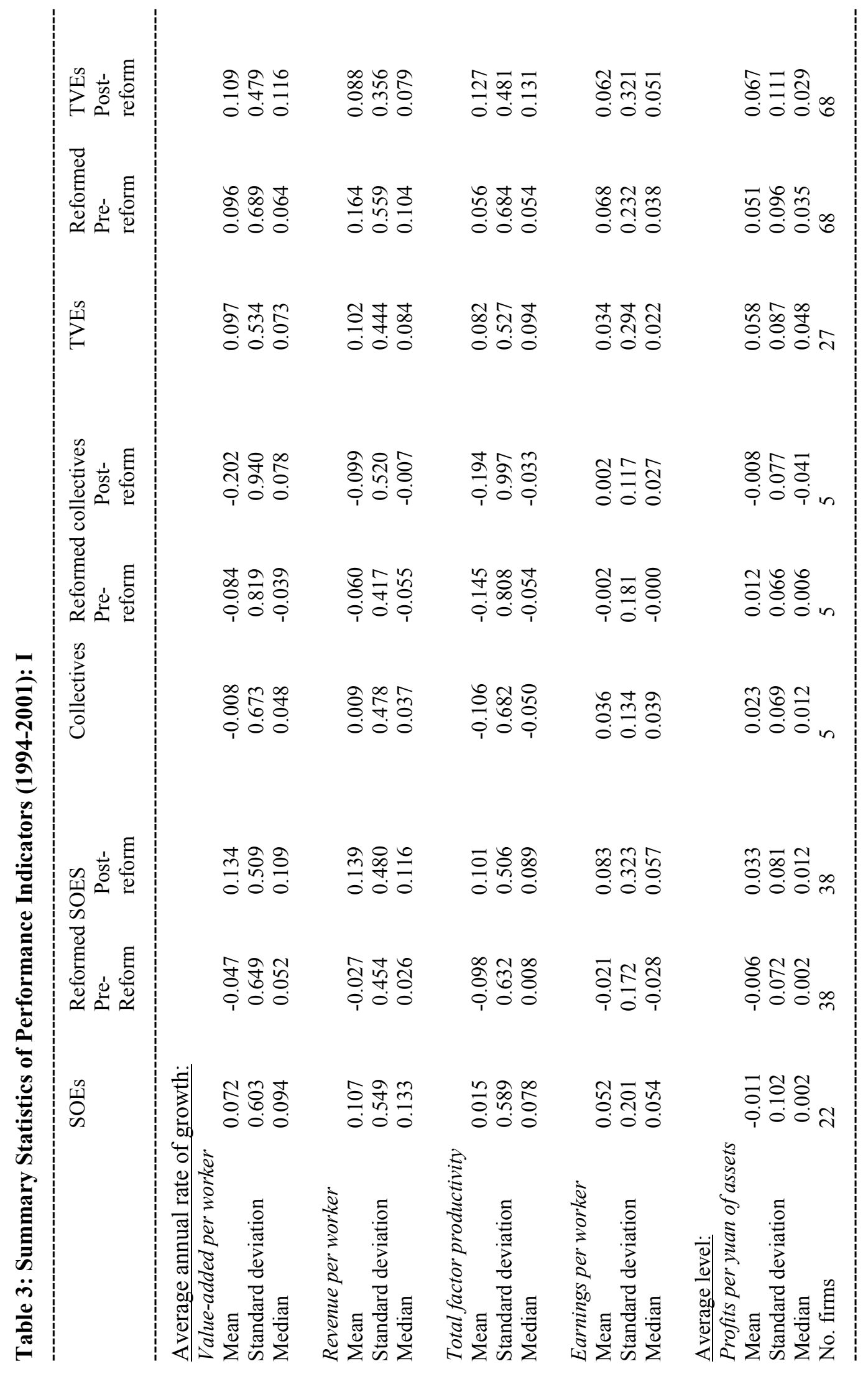




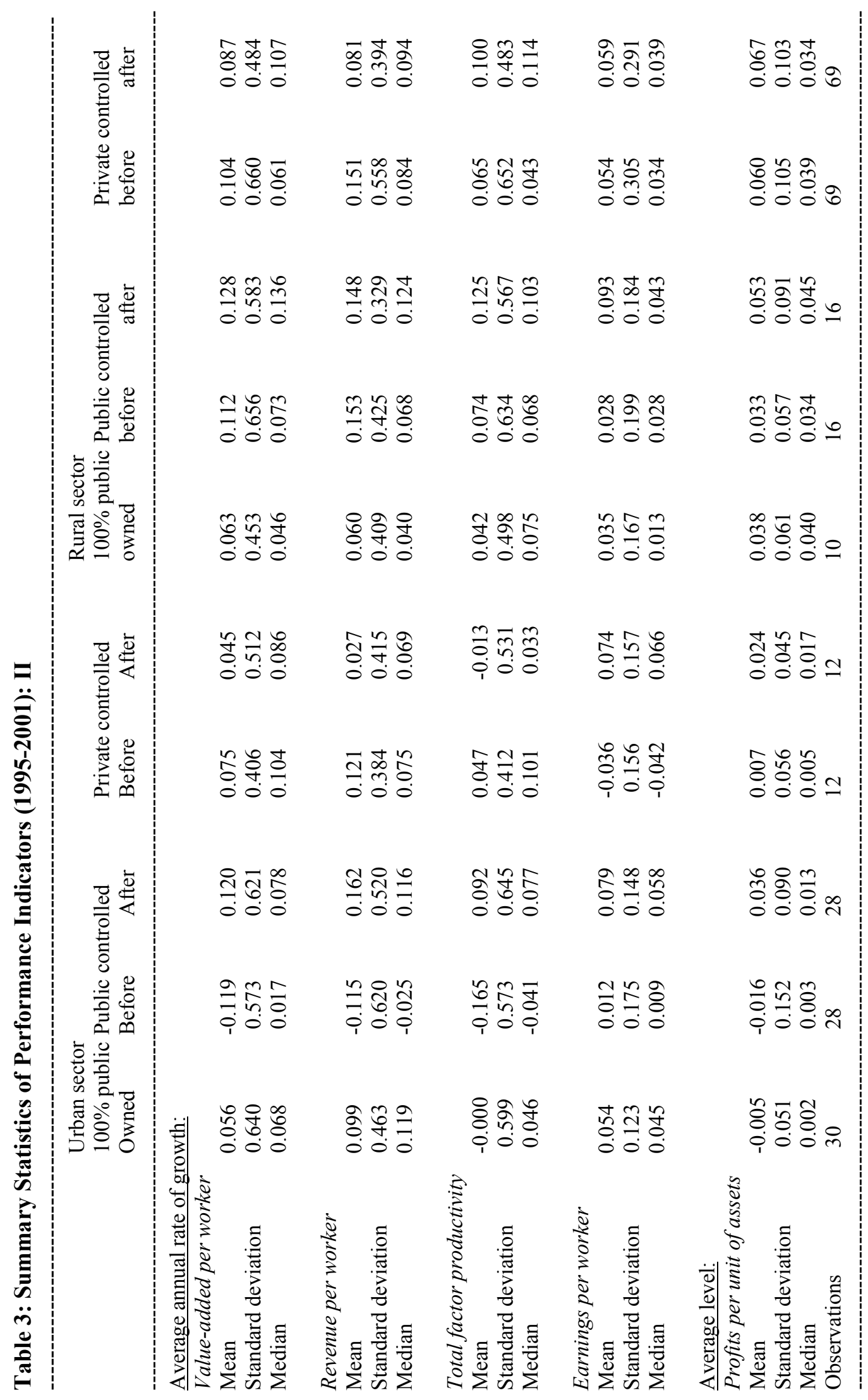


Table 4a. Estimates of Group Fixed-Effects Model (Reform Effects)

\begin{tabular}{|c|c|c|c|c|c|}
\hline & $\begin{array}{l}\text { Val.-added } \\
\text { Per worker }\end{array}$ & $\begin{array}{l}\text { Revenues } \\
\text { per worker }\end{array}$ & TFP & $\begin{array}{l}\text { Profits/ } \\
\text { assets }\end{array}$ & $\begin{array}{l}\text { Earnings } \\
\text { per worker }\end{array}$ \\
\hline \multicolumn{6}{|l|}{$\underline{\text { Reform effects }}$} \\
\hline Ref. SOEs & $\begin{array}{l}0.256 \\
(3.35)^{* * *}\end{array}$ & $\begin{array}{l}0.192 \\
(3.09)^{* * *}\end{array}$ & $\begin{array}{l}0.276 \\
(3.57)^{* * *}\end{array}$ & $\begin{array}{l}0.031 \\
(2.96)^{* * * *}\end{array}$ & $\begin{array}{l}0.045 \\
(1.57)\end{array}$ \\
\hline Ref. UCs & $\begin{array}{l}-0.143 \\
(-0.73)\end{array}$ & $\begin{array}{l}-0.066 \\
(-0.40)\end{array}$ & $\begin{array}{l}-0.044 \\
(-0.22)\end{array}$ & $\begin{array}{l}0.006 \\
(0.21)\end{array}$ & $\begin{array}{l}0.003 \\
(0.04)\end{array}$ \\
\hline Ref. TVEs & $\begin{array}{l}0.046 \\
(0.74)\end{array}$ & $\begin{array}{l}-0.039 \\
(-0.75)\end{array}$ & $\begin{array}{l}0.092 \\
(1.45)\end{array}$ & $\begin{array}{l}0.012 \\
(1.38)\end{array}$ & $\begin{array}{l}-0.016 \\
(-0.69)\end{array}$ \\
\hline \multicolumn{6}{|l|}{ Group effects } \\
\hline Ref. SOEs & $\begin{array}{l}-0.098 \\
(-1.31)\end{array}$ & $\begin{array}{l}-0.123 \\
(-2.03)^{* *}\end{array}$ & $\begin{array}{l}-0.059 \\
(-0.79)\end{array}$ & $\begin{array}{l}-0.008 \\
(-0.82)\end{array}$ & $\begin{array}{l}-0.049 \\
(-1.83)^{*}\end{array}$ \\
\hline Uref. UCs & $\begin{array}{c}0.012 \\
(0.12)\end{array}$ & $\begin{array}{l}-0.034 \\
(-0.41)\end{array}$ & $\begin{array}{l}0.117 \\
(1.16)\end{array}$ & $\begin{array}{l}0.031 \\
(2.16)^{* *}\end{array}$ & $\begin{array}{l}-0.049 \\
(-1.28)\end{array}$ \\
\hline Ref. UCs & $\begin{array}{l}-0.134 \\
(-0.82)\end{array}$ & $\begin{array}{l}-0.125 \\
(-0.94)\end{array}$ & $\begin{array}{l}-0.152 \\
(-0.95)\end{array}$ & $\begin{array}{l}-0.022 \\
(-0.98)\end{array}$ & $\begin{array}{l}-0.090 \\
(-1.48)\end{array}$ \\
\hline Uref. TVEs & $\begin{array}{r}0.097 \\
(1.53)\end{array}$ & $\begin{array}{l}0.059 \\
(1.15)\end{array}$ & $\begin{array}{l}0.228 \\
(3.54)^{* * *}\end{array}$ & $\begin{array}{l}0.041 \\
(4.53)^{* * * *}\end{array}$ & $\begin{array}{l}-0.144 \\
(-5.53) * * *\end{array}$ \\
\hline Ref. TVEs & $\begin{array}{l}0.102 \\
(1.76)^{*}\end{array}$ & $\begin{array}{l}0.123 \\
(2.59)^{* * *}\end{array}$ & $\begin{array}{l}0.195 \\
(3.32)^{* * *}\end{array}$ & $\begin{array}{l}0.032 \\
(3.91)^{* * *}\end{array}$ & $\begin{array}{l}-0.088 \\
(-3.69) * * *\end{array}$ \\
\hline $\begin{array}{l}\text { Initial level of } \\
\text { Performance } \\
\text { Loan/worker }\end{array}$ & $\begin{array}{l}-0.200 \\
(-10.29) * * * \\
0.002 \\
(3.47)^{* * *}\end{array}$ & $\begin{array}{l}-0.160 \\
(-9.37)^{* * *} \\
0.002 \\
(3.69)^{* * *}\end{array}$ & $\begin{array}{l}-0.219 \\
(-10.72)^{* * *} \\
0.001 \\
(2.15)^{* *}\end{array}$ & $\begin{array}{l}-0.488 \\
(-18.40)^{* * *} \\
0.000 \\
(0.08)\end{array}$ & $\begin{array}{l}-0.236 \\
(-12.97)^{* * *} \\
0.0004 \\
(1.69)^{*}\end{array}$ \\
\hline \multicolumn{6}{|l|}{ Time effects } \\
\hline 1996 & $\begin{array}{l}0.141 \\
(2.17)^{* *}\end{array}$ & $\begin{array}{l}0.060 \\
(1.12)\end{array}$ & $\begin{array}{l}0.122 \\
(1.87)^{*}\end{array}$ & $\begin{array}{l}-0.003 \\
(-0.35)\end{array}$ & $\begin{array}{l}0.042 \\
(1.71)^{*}\end{array}$ \\
\hline 1997 & $\begin{array}{l}0.127 \\
(1.97)^{* *}\end{array}$ & $\begin{array}{l}0.083 \\
(1.57)\end{array}$ & $\begin{array}{l}0.141 \\
(2.19)^{* *}\end{array}$ & $\begin{array}{l}-0.021 \\
(-2.31)^{* *}\end{array}$ & $\begin{array}{l}0.047 \\
(1.91)^{*}\end{array}$ \\
\hline 1998 & $\begin{array}{l}0.160 \\
(2.47)^{* *}\end{array}$ & $\begin{array}{l}0.060 \\
(1.11)\end{array}$ & $\begin{array}{l}0.169 \\
(2.61)^{* * *}\end{array}$ & $\begin{array}{l}0.004 \\
(0.43)\end{array}$ & $\begin{array}{l}0.122 \\
(4.95)^{* * *}\end{array}$ \\
\hline 1999 & $\begin{array}{l}0.202 \\
(3.05)^{* * *}\end{array}$ & $\begin{array}{l}0.089 \\
(1.64)^{*}\end{array}$ & $\begin{array}{l}0.197 \\
(2.99)^{* * * *}\end{array}$ & $\begin{array}{l}-0.004 \\
(-0.41)\end{array}$ & $\begin{array}{l}0.080 \\
(3.19)^{* * * *}\end{array}$ \\
\hline 2000 & $\begin{array}{l}0.091 \\
(1.30)\end{array}$ & $\begin{array}{l}0.091 \\
(1.57)\end{array}$ & $\begin{array}{l}0.093 \\
(1.32)\end{array}$ & $\begin{array}{c}0.004 \\
(0.37)\end{array}$ & $\begin{array}{l}0.134 \\
(5.04)^{* * * *}\end{array}$ \\
\hline 2001 & $\begin{array}{l}0.173 \\
(2.40)^{* *}\end{array}$ & $\begin{array}{l}0.110 \\
(1.84)^{*}\end{array}$ & $\begin{array}{l}0.180 \\
(2.51)^{* * *}\end{array}$ & $\begin{array}{l}0.001 \\
(0.03)\end{array}$ & $\begin{array}{l}0.130 \\
(4.73)^{* * *}\end{array}$ \\
\hline Industrial branch & $\begin{array}{l}\text { effects: } \\
\text { Yes }\end{array}$ & yes & yes & yes & yes \\
\hline Constant & $\begin{array}{l}0.525 \\
(4.55)^{* * *}\end{array}$ & $\begin{array}{l}0.703 \\
(6.67)^{* * *}\end{array}$ & $\begin{array}{l}0.211 \\
(2.00)^{* *}\end{array}$ & $\begin{array}{l}0.015 \\
(1.06)\end{array}$ & $\begin{array}{l}2.089 \\
(12.57) * * *\end{array}$ \\
\hline F-test & & & & & \\
\hline On zero slop & 5.36 & 5.18 & 5.97 & 13.79 & 8.34 \\
\hline $\begin{array}{l}\text { p-value } \\
\text { F-test }\end{array}$ & 0.0 & 0.0 & 0.0 & 0.0 & 0.0 \\
\hline On group effects & 1.62 & 3.66 & 3.97 & 7.17 & 7.57 \\
\hline $\mathrm{p}$-value & 0.15 & 0.0 & 0.0 & 0.0 & 0.0 \\
\hline Adjusted $\mathrm{R}^{2}$ & 0.11 & 0.10 & 0.13 & 0.24 & 0.15 \\
\hline Observations & 1,114 & 1,124 & 1,084 & 1,124 & 1,115 \\
\hline
\end{tabular}


Table 4b: Estimates of Group Fixed-effects Model (Privatization Effects)

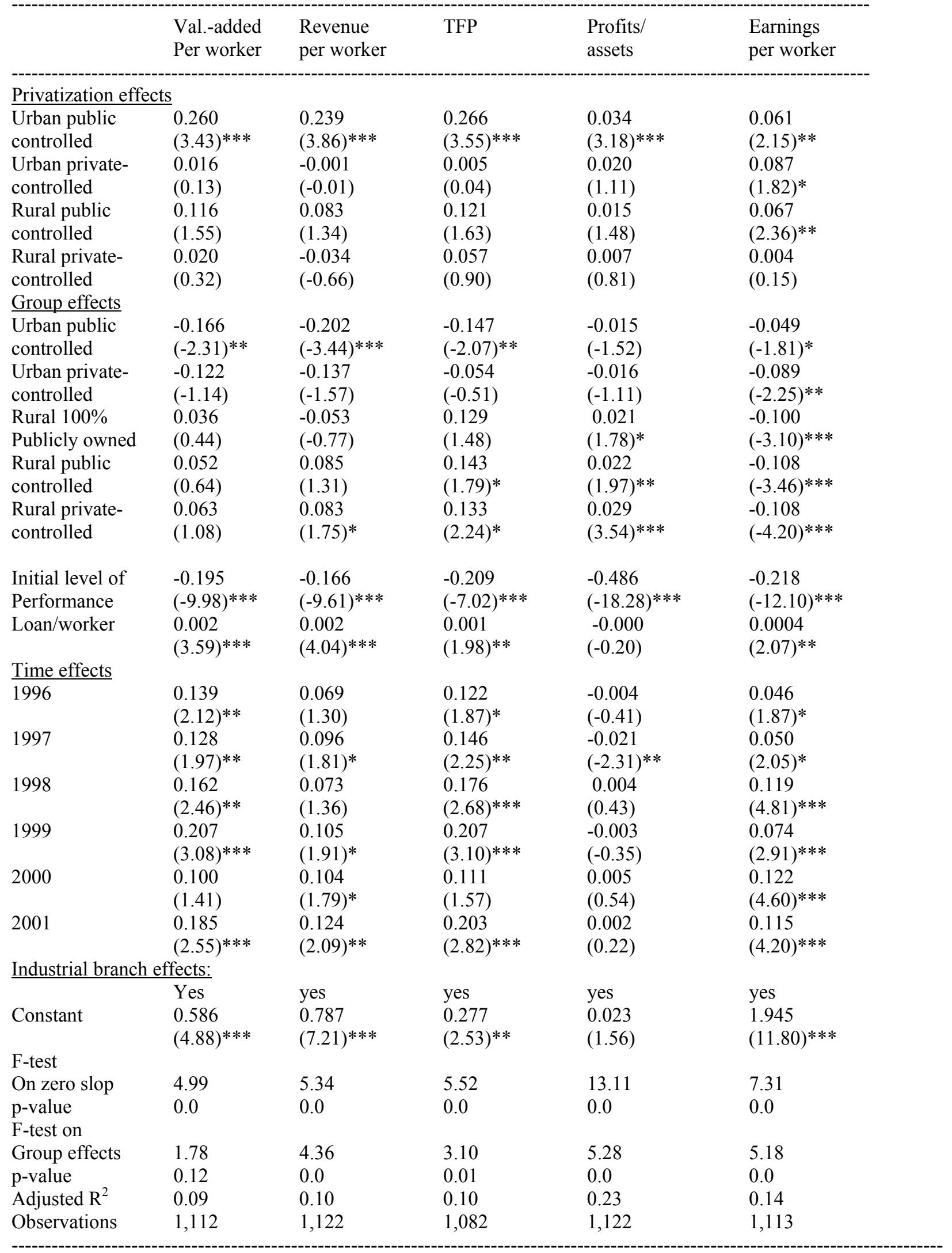


Notes: Dependent variables of val.-added per worker, revenue per worker, TFP (total factor productivity), and earnings per worker are measured as annual rates of growth, and the dependent variable of profits per yuan of assets is a change between periods t- 1 and t. *, **, and *** indicates the level of significance at $10 \%, 5 \%$, and $1 \%$, respectively. 
Table 5: Tests for Differential Group Effects

\begin{tabular}{|c|c|c|c|c|c|}
\hline & $\begin{array}{l}\text { Val-added } \\
\text { Per worker }\end{array}$ & $\begin{array}{l}\text { Revenue } \\
\text { per worker }\end{array}$ & $\begin{array}{l}\text { TFP } \\
\text { assets }\end{array}$ & $\begin{array}{l}\text { Profits/ } \\
\text { per worker }\end{array}$ & Earnings \\
\hline \multicolumn{6}{|c|}{ Tests based on reform-effects regressions } \\
\hline \multicolumn{6}{|c|}{$\mathrm{H}_{0}:$ reformed SOEs - unreformed SOEs $=0$} \\
\hline Performance gap & -0.098 & -0.123 & -0.059 & -0.008 & -0.051 \\
\hline T statistic & -1.31 & $-2.03 * *$ & -0.79 & -0.80 & $-1.83^{*}$ \\
\hline \multicolumn{6}{|c|}{$\mathrm{H}_{0}$ : reformed urban collectives - unreformed urban collectives $=0$} \\
\hline Performance gap & -0.122 & -0.091 & -0.034 & -0.050 & -0.046 \\
\hline T statistic & -0.63 & -0.48 & -1.18 & $-2.71 * * *$ & -1.01 \\
\hline \multicolumn{6}{|c|}{$\mathrm{H}_{0}$ : reformed TVEs - unreformed TVEs $=0$} \\
\hline Performance gap & 0.005 & 0.065 & -0.033 & -0.009 & 0.057 \\
\hline T statistic & 0.10 & 1.35 & -0.57 & -1.36 & $2.63 * * *$ \\
\hline \multicolumn{6}{|c|}{ Test based on privatization-effects regressions } \\
\hline \multicolumn{6}{|c|}{ Urban sector: } \\
\hline \multicolumn{6}{|c|}{$\mathrm{H}_{0}:$ Public controlled $-100 \%$ publicly owned $=0$} \\
\hline Performance gap & -0.165 & -0.202 & -0.148 & -0.016 & -0.049 \\
\hline T statistic & $-2.31 * *$ & $-3.44 * * *$ & $-2.07 * *$ & -1.52 & $-1.81^{*}$ \\
\hline \multicolumn{6}{|c|}{$\mathrm{H}_{0}$ : Private controlled $-100 \%$ publicly owned $=0$} \\
\hline Performance gap & -0.122 & -0.138 & -0.054 & -0.016 & -0.089 \\
\hline T statistic & -1.14 & -1.57 & -0.51 & -1.11 & $-2.25 * *$ \\
\hline \multicolumn{6}{|c|}{$\mathrm{H}_{0}$ : Private controlled - public controlled $=0$} \\
\hline Performance gap & 0.043 & 0.065 & 0.014 & -0.001 & -0.041 \\
\hline T statistic & 0.40 & 0.72 & 0.87 & 0.00 & -1.00 \\
\hline \multicolumn{6}{|l|}{ Rural sector: } \\
\hline \multicolumn{6}{|c|}{$\mathrm{H}_{0}$ : Public controlled $-100 \%$ publicly owned $=0$} \\
\hline Performance gap & 0.015 & 0.138 & 0.014 & 0.002 & -0.007 \\
\hline T statistic & 0.14 & $1.71 *$ & 0.14 & 0.10 & -0.20 \\
\hline \multicolumn{6}{|c|}{$\mathrm{H}_{0}$ : Private controlled $-100 \%$ publicly owned $=0$} \\
\hline Performance gap & 0.026 & 0.136 & 0.004 & 0.009 & 0.001 \\
\hline T statistic & 0.32 & $1.99 * *$ & 0.00 & 0.99 & 0.00 \\
\hline \multicolumn{6}{|c|}{$\mathrm{H}_{0}$ : Private controlled - public dominant $=0$} \\
\hline Performance gap & 0.012 & -0.003 & -0.010 & 0.007 & 0.008 \\
\hline T statistic & 0.17 & -0.00 & -0.14 & 0.88 & 0.30 \\
\hline
\end{tabular}

Notes: $* * *$, and $* * *$ indicates the level of significance at $10 \%, 5 \%$, and $1 \%$, respectively. 
Table 6a: Estimates of Firm Fixed-Effects Model (Reform Effects)

\begin{tabular}{|c|c|c|c|c|c|}
\hline $\begin{array}{l}\text { Dependent } \\
\text { Variable }\end{array}$ & $\begin{array}{l}\text { Val.-added } \\
\text { Per worker }\end{array}$ & $\begin{array}{l}\text { Revenue } \\
\text { per worker }\end{array}$ & TFP & $\begin{array}{l}\text { Profits/ } \\
\text { assets }\end{array}$ & $\begin{array}{l}\text { Earnings } \\
\text { per worker }\end{array}$ \\
\hline \multicolumn{6}{|l|}{ Reform effects: } \\
\hline$\overline{\text { Reformed SOE }}$ & $\begin{array}{l}0.271 \\
(3.02)^{* * *}\end{array}$ & $\begin{array}{l}0.148 \\
(2.04)^{* *}\end{array}$ & $\begin{array}{l}0.329 \\
(3.70)^{* * *}\end{array}$ & $\begin{array}{l}0.038 \\
(3.09)^{* * *}\end{array}$ & $\begin{array}{l}-0.007 \\
(-0.20)\end{array}$ \\
\hline Reformed UC & $\begin{array}{l}-0.393 \\
(-1.84)^{*}\end{array}$ & $\begin{array}{l}-0.263 \\
(-1.46)\end{array}$ & $\begin{array}{l}-0.371 \\
(-1.77)^{*}\end{array}$ & $\begin{array}{l}0.012 \\
(0.41)\end{array}$ & $\begin{array}{l}-0.092 \\
(-1.14)\end{array}$ \\
\hline Reformed TVE & $\begin{array}{l}0.067 \\
(1.07)\end{array}$ & $\begin{array}{l}0.019 \\
(0.36)\end{array}$ & $\begin{array}{l}0.144 \\
(2.32)^{* *}\end{array}$ & $\begin{array}{l}0.020 \\
(2.30)^{* *}\end{array}$ & $\begin{array}{l}-0.013 \\
(-0.55)\end{array}$ \\
\hline $\begin{array}{l}\text { Initial level of } \\
\text { performance }\end{array}$ & $\begin{array}{l}-0.663 \\
(-21.65)^{* * *}\end{array}$ & $\begin{array}{l}-0.584 \\
(-20.38)^{* * *}\end{array}$ & $\begin{array}{l}-0.685 \\
(-22.33) * * *\end{array}$ & $\begin{array}{l}-0.869 \\
(-27.48)^{* * *}\end{array}$ & $\begin{array}{l}-0.663 \\
(-23.37)^{* * *}\end{array}$ \\
\hline Loan/per worker & $\begin{array}{l}0.002 \\
(3.35)^{* * *}\end{array}$ & $\begin{array}{l}0.002 \\
(2.87)^{* * *}\end{array}$ & $\begin{array}{l}0.001 \\
(2.01)^{* *}\end{array}$ & $\begin{array}{l}-0.000 \\
(-0.37)\end{array}$ & $\begin{array}{l}0.0002 \\
(0.77)\end{array}$ \\
\hline \multicolumn{6}{|l|}{ Time effects: } \\
\hline 1996 & $\begin{array}{l}0.107 \\
(1.86)^{*}\end{array}$ & $\begin{array}{l}0.083 \\
(1.71)^{*}\end{array}$ & $\begin{array}{l}0.056 \\
(0.98)\end{array}$ & $\begin{array}{l}-0.008 \\
(-0.93)\end{array}$ & $\begin{array}{l}0.038 \\
(1.75)^{*}\end{array}$ \\
\hline 1997 & $\begin{array}{l}0.140 \\
(2.44)^{* *}\end{array}$ & $\begin{array}{l}0.152 \\
(3.15)^{* * *}\end{array}$ & $\begin{array}{l}0.100 \\
(1.76)^{*}\end{array}$ & $\begin{array}{l}-0.028 \\
(-3.44)^{* * *}\end{array}$ & $\begin{array}{l}0.058 \\
(2.65)^{* * *}\end{array}$ \\
\hline 1998 & $\begin{array}{l}0.214 \\
(3.66)^{* * *}\end{array}$ & $\begin{array}{l}0.182 \\
(3.68)^{* * *}\end{array}$ & $\begin{array}{l}0.159 \\
(2.75)^{* * *}\end{array}$ & $\begin{array}{l}-0.011 \\
(-1.37)\end{array}$ & $\begin{array}{l}0.153 \\
(6.93)^{* * *}\end{array}$ \\
\hline 1999 & $\begin{array}{l}0.310 \\
(5.14)^{* * *}\end{array}$ & $\begin{array}{l}0.247 \\
(4.82)^{* * *}\end{array}$ & $\begin{array}{l}0.221 \\
(3.72)^{* * *}\end{array}$ & $\begin{array}{l}-0.013 \\
(-1.60)\end{array}$ & $\begin{array}{l}0.157 \\
(6.80)^{* * *}\end{array}$ \\
\hline 2000 & $\begin{array}{l}0.264 \\
(4.00)^{* * *}\end{array}$ & $\begin{array}{l}0.288 \\
(5.13)^{* * *}\end{array}$ & $\begin{array}{l}0.162 \\
(2.50)^{* * *}\end{array}$ & $\begin{array}{l}-0.007 \\
(-0.74)\end{array}$ & $\begin{array}{l}0.230 \\
(9.14)^{* * *}\end{array}$ \\
\hline 2001 & $\begin{array}{l}0.359 \\
(5.31)^{* * *}\end{array}$ & $\begin{array}{l}0.346 \\
(5.95)^{* * *}\end{array}$ & $\begin{array}{l}0.258 \\
(3.88)^{* * *}\end{array}$ & $\begin{array}{l}-0.006 \\
(-0.64)\end{array}$ & $\begin{array}{l}0.262 \\
(9.90)^{* * *}\end{array}$ \\
\hline Constant & $\begin{array}{l}1.808 \\
(19.11)^{* * *}\end{array}$ & $\begin{array}{l}2.328 \\
(19.93)^{* * *}\end{array}$ & $\begin{array}{l}1.068 \\
(15.75)^{* * *}\end{array}$ & $\begin{array}{l}0.032 \\
(5.31)^{* * *}\end{array}$ & $\begin{array}{l}5.549 \\
(23.29) * * *\end{array}$ \\
\hline $\mathrm{R}^{2}$ & 0.086 & 0.056 & 0.091 & 0.202 & 0.010 \\
\hline \multicolumn{6}{|c|}{ F statistic on zero slop: } \\
\hline & 46.56 & 39.60 & 48.85 & 71.87 & 53.41 \\
\hline $\mathrm{p}$ value & 0.0 & 0.0 & 0.0 & 0.0 & 0.0 \\
\hline \multicolumn{6}{|c|}{ F statistic on zero fixed effects: } \\
\hline & 2.87 & 2.84 & 3.07 & 2.91 & 3.09 \\
\hline $\mathrm{p}$ value & 0.0 & 0.0 & 0.0 & 0.0 & 0.0 \\
\hline Observations & 1,114 & 1,124 & 1,084 & 1,128 & 1,115 \\
\hline
\end{tabular}


Table 6b: Estimates of Firm Fixed-Effects Model (Privatization Effects)

\begin{tabular}{|c|c|c|c|c|c|}
\hline $\begin{array}{l}\text { Dependent } \\
\text { Variable }\end{array}$ & $\begin{array}{l}\text { Val.-added } \\
\text { Per worker }\end{array}$ & $\begin{array}{l}\text { Revenue } \\
\text { per worker }\end{array}$ & TFP & $\begin{array}{l}\text { Profits/ } \\
\text { assets }\end{array}$ & $\begin{array}{l}\text { Earnings } \\
\text { per worker }\end{array}$ \\
\hline \multicolumn{6}{|c|}{ Privatization effects: } \\
\hline Urban public & 0.178 & 0.198 & 0.207 & 0.047 & 0.068 \\
\hline Controlled & $(1.99)^{* *}$ & $(2.65) * * *$ & $(2.34)^{* *}$ & $(3.78)^{* * *}$ & $(2.02)^{*}$ \\
\hline Urban private & -0.178 & -0.105 & -0.147 & 0.018 & -0.016 \\
\hline Controlled & $(-1.33)$ & $(-0.94)$ & $(-1.08)$ & $(0.94)$ & $(-0.33)$ \\
\hline Rural public & 0.128 & 0.151 & 0.079 & -0.003 & 0.045 \\
\hline Controlled & $(1.49)$ & $(2.09) * *$ & $(0.93)$ & $(-0.23)$ & $(1.41)$ \\
\hline Rural private & 0.039 & 0.002 & 0.108 & 0.022 & 0.009 \\
\hline Controlled & $(0.60)$ & $(0.21)$ & $(1.68)^{*}$ & $(2.38)^{* *}$ & $(0.40)$ \\
\hline Initial level of & -0.672 & -0.585 & -0.678 & -0.875 & -0.655 \\
\hline Performance & $(-21.80)^{* * *}$ & $(-20.37)^{* * *}$ & $(-21.93)^{* * *}$ & $(-27.54)^{* * *}$ & $(-22.86)^{* * *}$ \\
\hline \multirow[t]{2}{*}{ Loan/per worker } & 0.003 & 0.002 & 0.002 & 0.000 & 0.0003 \\
\hline & $(3.54)^{* * *}$ & $(3.14)^{* * *}$ & $(2.18)^{* *}$ & $(0.05)$ & $(0.99)$ \\
\hline \multicolumn{6}{|l|}{ Time effects: } \\
\hline \multirow[t]{2}{*}{1996} & 0.107 & 0.087 & 0.061 & -0.007 & 0.039 \\
\hline & $(1.85)^{*}$ & $(1.80)^{*}$ & $(1.06)$ & $(-0.85)$ & $(1.77)^{*}$ \\
\hline \multirow[t]{2}{*}{1997} & 0.141 & 0.157 & 0.109 & -0.027 & 0.057 \\
\hline & $(2.44)^{* *}$ & $(3.25)^{* * *}$ & $(1.89)^{*}$ & $(-3.30)^{* * *}$ & $(2.63)^{* * *}$ \\
\hline \multirow[t]{2}{*}{1998} & 0.225 & 0.189 & 0.178 & -0.010 & 0.148 \\
\hline & $(3.79)^{* * *}$ & $(3.25)^{* * *}$ & $(3.01)^{* * *}$ & $(-1.23)$ & $(6.64)^{* * *}$ \\
\hline \multirow[t]{2}{*}{1999} & 0.324 & 0.254 & 0.243 & -0.013 & 0.146 \\
\hline & $(5.27)^{* * *}$ & $(3.79)^{* * *}$ & $(4.00) * * *$ & $(-1.47)$ & $(6.29)^{* * *}$ \\
\hline \multirow[t]{2}{*}{2000} & 0.284 & 0.291 & 0.196 & -0.005 & 0.211 \\
\hline & $(4.26)^{* * *}$ & $(5.21)^{* * *}$ & $(2.99)^{* * *}$ & $(-0.60)$ & $(8.41)^{* * *}$ \\
\hline \multirow[t]{2}{*}{2001} & 0.386 & 0.356 & 0.298 & -0.004 & 0.242 \\
\hline & $(5.65)^{* * *}$ & $(6.15)^{* * *}$ & $(4.44) * * *$ & $(-0.51)$ & $(9.21)^{* * *}$ \\
\hline \multirow[t]{2}{*}{ Constant } & 1.795 & 2.309 & 1.053 & 0.030 & 5.473 \\
\hline & $(18.72)^{* * *}$ & $(19.69) * * *$ & $(15.16)^{* * *}$ & $(4.82)^{* * *}$ & $(22.74)^{* * *}$ \\
\hline $\mathrm{R}^{2}$ & 0.081 & 0.055 & 0.087 & 0.198 & 0.095 \\
\hline \multicolumn{6}{|c|}{ F statistic on zero slop: } \\
\hline & 41.89 & 36.73 & 43.14 & 66.22 & 46.99 \\
\hline p-value & 0.0 & 0.0 & 0.0 & 0.0 & 0.0 \\
\hline \multicolumn{6}{|c|}{ F statistic on zero firm-fixed effects: } \\
\hline & 2.84 & 2.88 & 2.97 & 2.90 & 2.98 \\
\hline p-value & 0.0 & 0.0 & 0.0 & 0.0 & 0.0 \\
\hline Observations & 1,112 & 1,112 & 1,082 & 1,122 & 1,113 \\
\hline
\end{tabular}

Notes: Dependent variables of val.-added per worker, revenue per worker, TFP (total factor productivity), and earnings per worker are measured as annual rates of growth, and the dependent variable of profits per yuan of assets is a change between periods t-1 and t. *,**, and *** indicates the level of significance at $10 \%, 5 \%$, and $1 \%$, respectively. 


\section{DAVIDSON INSTITUTE WORKING PAPER SERIES - Most Recent Papers}

The entire Working Paper Series may be downloaded free of charge at: www.wdi.bus.umich.edu

CURRENT AS OF 3/15/04

\begin{tabular}{|c|c|c|}
\hline Publication & Authors & Date \\
\hline $\begin{array}{l}\text { No. 668: Enterprise Restructuring and Firm Performance: } \\
\text { A Comparison of Rural and Urban Enterprises in Jiangsu Province }\end{array}$ & $\begin{array}{l}\text { Xiao-yuan Dong, Louis } \\
\text { Putterman and Bulent Unel }\end{array}$ & Mar. 2004 \\
\hline $\begin{array}{l}\text { No. 667: A Tale of Two Provinces: The Institutional Environment and } \\
\text { Foreign Ownership in China }\end{array}$ & Yasheng Huang and Wenhua Di & Mar. 2004 \\
\hline $\begin{array}{l}\text { No. 666: Ownership Characteristics and Access to Finance: } \\
\text { Evidence from a Survey of Large Privatised Companies in Hungary } \\
\text { and Poland }\end{array}$ & $\begin{array}{l}\text { Natalia Isachenkova and Tomasz } \\
\text { Mickiewicz }\end{array}$ & Mar. 2004 \\
\hline $\begin{array}{l}\text { No. 665: Testing Creditor Moral Hazard in Sovereign Bond Markets: } \\
\text { A Unified Theoretical Approach and Empirical Evidence }\end{array}$ & $\begin{array}{l}\text { Ayşe Y. Evrensel and Ali M. } \\
\text { Kutan }\end{array}$ & Mar. 2004 \\
\hline $\begin{array}{l}\text { No. 664: Assessing Equilibrium Exchange Rates in CEE Acceding } \\
\text { Countries: Can We Have DEER with BEER without FEER? }\end{array}$ & Balázs Égert & Feb. 2004 \\
\hline $\begin{array}{l}\text { No. 663: Modelling stock returns in the G-7 and in selected CEE } \\
\text { economies: A non-linear GARCH approach }\end{array}$ & Balázs Égert and Yosra Koubaa & Feb. 2004 \\
\hline $\begin{array}{l}\text { No. 662: Institutional Change and Product Composition: Does the Initial } \\
\text { Quality of Institutions Matter? }\end{array}$ & $\begin{array}{l}\text { Johannes Moenius and Daniel } \\
\text { Berkowitz }\end{array}$ & Feb. 2004 \\
\hline No. 661: Dual track liberalization: With and without losers & $\begin{array}{l}\text { Jiahua Che and Giovanni } \\
\text { Facchini }\end{array}$ & Feb. 2004 \\
\hline $\begin{array}{l}\text { No. 660: Who Is in Favor of Enlargement? Determinants of Support for } \\
\text { EU Membership in the Candidate Countries' Referenda }\end{array}$ & Orla Doyle and Jan Fidrmuc & Feb. 2004 \\
\hline $\begin{array}{l}\text { No. 659: Creditor Moral Hazard in Equity Markets: } \\
\text { A Theoretical Framework and Evidence from Indonesia and Korea }\end{array}$ & $\begin{array}{l}\text { Ayşe Y. Evrensel and Ali M. } \\
\text { Kutan }\end{array}$ & Feb. 2004 \\
\hline No. 658: Worsening of the Asian Financial Crisis: Who is to Blame? & $\begin{array}{l}\text { Brasukra G. Sudjana and Ali M. } \\
\text { Kutan }\end{array}$ & Feb. 2004 \\
\hline $\begin{array}{l}\text { No. 657: European Integration, Productivity Growth and Real } \\
\text { Convergence }\end{array}$ & Taner M. Yigit and Ali M. Kutan & Feb. 2004 \\
\hline $\begin{array}{l}\text { No. 656: The Impact of News, Oil Prices, and Global Market } \\
\text { Developments on Russian Financial Markets }\end{array}$ & Bernd Hayo and Ali M. Kutan & Feb. 2004 \\
\hline No. 655: Politics and Economic Reform in Malaysia & Bryan K. Ritchie & Feb. 2004 \\
\hline No. 654: The Evolution of Income Inequality in Rural China & $\begin{array}{l}\text { Dwayne Benjamin, Loren Brandt } \\
\text { and John Giles }\end{array}$ & Feb. 2004 \\
\hline $\begin{array}{l}\text { No. 653: The Sources of Real Exchange Fluctuations in } \\
\text { Developing Countries : an Econometric Investigation }\end{array}$ & Imed Drine and Christophe Rault & Feb. 2004 \\
\hline $\begin{array}{l}\text { No. 652: Ownership, Control and Corporate Performance After } \\
\text { Large-Scale Privatization }\end{array}$ & $\begin{array}{l}\text { Jan Hanousek, Evzen Kocenda } \\
\text { and Jan Svejnar }\end{array}$ & Feb. 2004 \\
\hline $\begin{array}{l}\text { No. 651: Czech Social Reform/Non-reform: Routes, Actors and } \\
\text { Problems }\end{array}$ & Jiri Vecernik & Feb. 2004 \\
\hline $\begin{array}{l}\text { No. 650: Financial Integration, Exchange Rate Regimes in CEECs, } \\
\text { and Joining the EMU: Just Do It... }\end{array}$ & Maurel Mathilde & Feb. 2004 \\
\hline $\begin{array}{l}\text { No. 649: Corporate Investments, Liquidity and Bank Financing: } \\
\text { Empirical Evidence from an Emerging Market }\end{array}$ & Arun Khanna & Feb. 2004 \\
\hline $\begin{array}{l}\text { No. 648: Financial Constraints in Investment - Foreign Versus } \\
\text { Domestic Firms. Panel Data Results From Estonia, 1995-1999. }\end{array}$ & $\begin{array}{l}\text { Tomasz Mickiewicz, Kate Bishop } \\
\text { and Urmas Varblane }\end{array}$ & Feb. 2004 \\
\hline $\begin{array}{l}\text { No. 647: Legal Minimum Wages and the Wages of Formal and Informal } \\
\text { Sector Workers in Costa Rica }\end{array}$ & $\begin{array}{l}\text { T. H. Gindling and Katherine } \\
\text { Terrell }\end{array}$ & Feb. 2004 \\
\hline $\begin{array}{l}\text { No. 646: Employment Expectations and Gross Flows by Type of Work } \\
\text { Contract }\end{array}$ & $\begin{array}{l}\text { Catalina Amuedo-Dorantes and } \\
\text { Miguel Á. Malo }\end{array}$ & Jan. 2004 \\
\hline $\begin{array}{l}\text { No. 645: Transition on the Shop Floor - The Restructuring of a Weaving } \\
\text { Mill, Hungary 1988-97 }\end{array}$ & János Köllő & Jan. 2004 \\
\hline $\begin{array}{l}\text { No. 644: Fighting "Low Equilibria" by Doubling the Minimum Wage? } \\
\text { Hungary's Experiment }\end{array}$ & Gábor Kertei and János Köllő & Jan. 2004 \\
\hline $\begin{array}{l}\text { No. 643: Mind the Break! Accounting for Changing Patterns of Growth } \\
\text { during Transition }\end{array}$ & Jan Fidrmuc and Ariane Tichit & Jan. 2004 \\
\hline
\end{tabular}

